\title{
Clinical and Laboratory Parameters of Mast Cell Activation as Basis for the Formulation of Diagnostic Criteria
}

\author{
Peter Valent ${ }^{a}$ Hans-Peter Horny ${ }^{b}$ Massimo Triggiani ${ }^{c}$ Michel Arock ${ }^{d}$ \\ a Department of Internal Medicine I, Division of Hematology and Hemostaseology, Medical University of Vienna, \\ Vienna, Austria; ${ }^{\mathrm{b}}$ Institute of Pathology Ansbach, Ansbach, Germany; ' ${ }^{\mathrm{C}}$ Division of Allergy and Clinical Immunology,

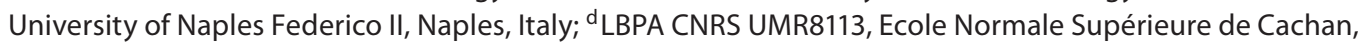 \\ Cachan, France
}

\section{Key Words}

Mast cells $\cdot$ Anaphylaxis $\cdot$ Allergy $\cdot$ Histamine $\cdot \lg \mathrm{E}$

\begin{abstract}
Mast cell (MC) activation occurs in a number of different pathologic conditions. Acute activation is commonly seen in patients with allergic reactions, with consecutive massive release of vasoactive and proinflammatory mediator substances from MCs, leading to the clinical signs and symptoms of anaphylaxis. In these patients, serum tryptase concentrations usually increase subtantially above baseline levels. Chronic MC activation is more difficult to diagnose, especially when symptoms are mild or atypical, and no underlying disease is found. In these patients, serum tryptase levels usually are normal. In a smaller group of patients, tryptase levels are constantly elevated and may point to an occult form of mastocytosis. These patients have to be examined for MC monoclonality, other criteria of a primary MC disease, non-MC hematopoietic neoplasms, and reactive disorders producing chronic MC activation or MC accumulation. In most patients in whom MC activation is found, histamine-induced symptoms can be documented and usually respond to treatment with histamine receptor antagonists or MC stabilizers. If this is not the case, alternative explanations for symptoms and differential diagnoses have to be considered.

Copyright $\odot 2011$ S. Karger AG, Basel
\end{abstract}

\section{Introduction}

Clinical symptoms originating from mast cell (MC) activation with release of granular mediators may be one of the most frequently recorded features in general medicine. Symptoms range from mild headache or fatigue to ulcerative gastrointestinal disease, from itching to lifethreatening hypotension and anaphylaxis, and from tachycardia or musculoskeletal pain to neurologic or even psychiatric symptoms [1-3]. The heterogeneity of symptoms may be explained by the different MC-derived mediators involved, local tissue-specific factors, comorbidities and the intensity of MC activation [3-6]. Symptoms may present as an acute attack or as chronic recurrent episodes [3-6]. An underlying disease, such as an allergic disorder, is found in most patients [6-8]. Other causative disorders such as systemic mastocytosis (SM) are less frequent [9-13]. However, in patients who develop severe anaphylaxis after exposure to hymenoptera venom in the absence of specific (detectable) IgE, an underlying occult form of SM is diagnosed quite frequently [9-15]. In such patients, additional signs and symptoms of SM may be found, such as an 'unexplained' osteopathy and/or gastrointestinal problems $[14,15]$. Other patients have similar symptoms without involvement of the MC lineage; this is important because other underlying disorders have to be considered.

\section{KARGER}

Fax +41613061234 E-Mail karger@karger.ch www.karger.com
Correspondence to: Prof. Peter Valent

Department of Internal Medicine I, Division of Hematology and Hemostaseology

Medical University of Vienna, Währinger Gürtel 18-20

AT-1090 Vienna (Austria)

Tel. +43 140400 6085, E-Mail peter.valent@meduniwien.ac.at 
Although regarded as an increasingly important issue, only a few reliable parameters of MC activation are available. The present paper provides an overview of our knowledge on MC activation and related symptoms and features, together with a discussion on clinical and laboratory parameters that can be employed in daily practice.

\section{Clinical Features}

There are a number of clinical features that may provide direct or indirect evidence for MC activation. One such feature is the presence of a primary MC disease (MC neoplasm = mastocytosis) often manifesting with skin lesions. MC activation with mild or severe symptoms may occur in all variants of mastocytosis independent of the burden of MC and the presence or absence of skin lesions [11-17]. Even in cases with 'subdiagnostic' accumulations of monoclonal and thus neoplastic MC in the tissues, MC activation may occur and may represent a relevant clinical problem [12, 13, 18-20]. This condition, which may represent a prephase of $\mathrm{SM}$, has recently been termed 'monoclonal MC activation syndrome' (monoclonal MCAS) $[18,19]$. In other cases, MC activation is the first and only clinical symptom of an otherwise occult SM, which may be a diagnostic challenge in patients who have no skin lesions [18-21].

Typical clinical findings that would point to the presence of an occult SM include severe reactions to hymenoptera stings without overt (documented or known) allergy, unexplained severe osteoporosis (especially in men), unexplained severe anaphylactic reactions to drugs (without documented allergy), or an unexplained severe ulcerative disorder of the gastrointestinal tract [17-21]. If these features are present (especially two or more of them) and symptoms are responsive to histamine receptor (HR) antagonists (HR1 or HR2 blockers) or MC stabilizing agents (e.g. cromolyn sodium or ketotifen), a primary MC disease (SM) or MCAS has to be considered [20-22]. A reliable marker in suspected (occult) SM is the basal serum tryptase level. Notably, in most patients with SM, basal tryptase levels are elevated to greater than $20 \mathrm{ng} / \mathrm{ml}$ even if skin lesions are not detectable [23-25].

Other patients suffer from symptoms of local MC activation, such as flushing, acute urticaria, angioedema, asthma, rhinitis, or gastrointestinal cramping [15-22]. In all these situations, the patient should be explored for signs of systemic MC activation and (occult) mastocytosis [23-25]. A straightforward approach is to ask for additional systemic histamine-induced symptoms, such as headache, hypotension and diarrhea. Sometimes, it may be quite difficult to define whether such symptoms are caused by histamine or other mediators. A documented response to HR antagonists is a relatively safe indication of histamine involvement and can therefore be judged as an important diagnostic finding in these patients $[15,22]$.

However, MCs produce and release not only histamine but also other mediators that may cause more or less specific symptoms (table 1) [2, 26]. Therefore, not all patients may respond to HR blockers even when suffering from an MC disorder or allergy. Moreover, histamine is not only produced by MCs but also by blood basophils. In other words, the identification of histamine as primary mediator in a pathologic reaction does not necessarily mean that MCs (normal, reactive or neoplastic) are the (only) cells involved in the disease process.

When no underlying MC neoplasm is found, but histamine-related symptoms are recorded, it is essential to define whether the patient is suffering from an allergic or atopic disease, or another underlying disease that may trigger MC activation and symptoms. Certain clinical findings and symptoms, like seasonal rhinitis, urticaria, bronchial asthma, or atopic dermatitis, would argue for an allergic disease or atopy (as primary trigger of $\mathrm{MC}$ activation). In many patients, the triggering agent (allergen or autoallergen) is known (identified in an allergy test). If this is not the case, the patient may suffer from an idiopathic form of $\mathrm{MC}$ activation or from an unrelated disorder $[9,27]$. An interesting hypothesis is that some of these patients may suffer from a syndrome called 'histamine intolerance', a condition that has been considered to result from (relative) diamine oxidase (DAO) deficiency $[28,29]$. However, because of analytical limitations, it is difficult to discriminate between overt substrate overload and DAO deficiency in biological fluids. Symptoms caused by histamine and other MC-derived mediators are summarized in table 1 .

\section{Laboratory Parameters}

Only a few laboratory parameters indicating MC activation with sufficient precision and specificity are available.

Histamine and Histamine Metabolites in Plasma and Urine

An established approach is to measure histamine and/ or its metabolites in plasma and urine during an attack [30-34]. However, as mentioned, histamine is also ex- 
Table 1. Clinical features and symptoms: possible role of MC-derived mediators

\begin{tabular}{|c|c|}
\hline Feature(s) & Mediator(s) \\
\hline Hypotension, vascular instability & histamine, $\mathrm{PGD}_{2}$, LTs, PAF \\
\hline Increased vascular permeability & histamine, VEGF \\
\hline Increased local angiogenesis & VEGF, OSM \\
\hline Tissue fibrosis & TGF- $\beta$, OSM, FGF \\
\hline Eosinophilia & interleukins (IL-3, IL-5) \\
\hline Lymphocytic infiltration & interleukins, chemokines, histamine \\
\hline Anticoagulation, bleeding & heparin \\
\hline Fibrinolysis, bleeding & $\mathrm{tPA}$, heparin \\
\hline Fibrinogenolysis & $\beta$-tryptase \\
\hline \multicolumn{2}{|l|}{ Skin } \\
\hline Pruritus & histamine \\
\hline Urticaria & histamine, LTs \\
\hline Edema & histamine, LTs, VEGF \\
\hline \multicolumn{2}{|l|}{ Lung } \\
\hline Bronchoconstriction & histamine, $\mathrm{PGD}_{2}$, LT, PAF, endotheli \\
\hline Pulmonary edema & histamine, LTs, PAF \\
\hline \multicolumn{2}{|l|}{ Gastrointestinal tract } \\
\hline Gastric hypersecretion & histamine, LTs \\
\hline Cramping, abdominal pain & histamine, LTs, PAF \\
\hline Diarrhea & histamine \\
\hline \multicolumn{2}{|l|}{ Skeletal system } \\
\hline Bone remodeling & tryptase, chymotryptic proteases, FGI \\
\hline Osteoporosis & heparin, proteases \\
\hline
\end{tabular}

pressed (and released) in basophils, and the result may depend on a number of variables such as food intake, drug intake, and the time interval between the event and sampling. When plasma histamine levels are measured, it is important to be aware of preanalytical caveats and the exact procedure [34]. Nevertheless, when performed in an appropriate manner, measurement of histamine and its metabolites may be as accurate as tryptase in determining $\mathrm{MC}$ activation. Likewise, in a patient with known MC disease or allergic disease (involving MCs) and apparent mediator-related symptoms, histamine metabolites may well serve as diagnostic markers to confirm $\mathrm{MC}$ activation [30-34]. On the other hand, we would like to point out that tryptase must be regarded as the more reliable and more specific parameter of MC activation when compared to histamine.

\section{Serum Tryptase Measurements}

The most widely used approach is to determine total tryptase levels (all enzyme variants) by immunoassay $[23-25,35]$. During an allergic reaction or other reaction leading to MC degranulation, the levels of released tryptases and thus total serum tryptase levels increase [35]. However, there is no consensus on the minimal increase in serum tryptase (above basal levels) required to regard an event as an 'MC activation-related' event. An increase from normal $(<10-15 \mathrm{ng} / \mathrm{ml}$ depending on the laboratory) to greater than $20 \mathrm{ng} / \mathrm{ml}$ or from elevated baseline $(>15 \mathrm{ng} / \mathrm{ml}$ ) by at least $20 \%$ should be regarded as a relatively safe indication of $\mathrm{MC}$ activation. In many patients, basal tryptase levels may not be available at the time of the first diagnosis (a first event) but may only be known after complete resolution of symptoms when the test is repeated. In fact, serum tryptase levels need to be repeated several days after complete resolution of symptoms. In patients with elevated basal tryptase levels, a search for an underlying $\mathrm{MC}$ disease (SM), chronic MC activation, or a myeloid non-MC lineage neoplasm should be initiated [23-25]. End-stage kidney disease (hemodialysis patients) is another potential reason for elevated tryptase levels (table 2) [25, 36, 37]. Moreover, even some apparently healthy individuals may have a slightly increased 
Table 2. Conditions/disorders that can present with elevated basal serum tryptase ${ }^{1}$

\begin{tabular}{ll}
\hline Condition/disease & Source of tryptase \\
\hline Idiopathic & unknown \\
\hline End-stage kidney disease ${ }^{2}$ & normal MCs ${ }^{1}$ \\
\hline Helminth infection & reactive MCs \\
\hline MCAS & $\begin{array}{l}\text { activated MCs (monoclonal or } \\
\text { polyclonal) }\end{array}$ \\
\hline Allergic/atopic disorders & $\begin{array}{l}\text { activated MCs and/or activat- } \\
\text { ed basophils }\end{array}$ \\
\hline $\begin{array}{l}\text { SM } \\
\text { Occult SM }\end{array}$ & $\begin{array}{l}\text { neoplastic MCs } \\
\text { neoplastic MCs }\end{array}$ \\
\hline $\begin{array}{l}\text { Myelodysplastic syndromes } \\
\text { neoplastic MCs or/and baso- } \\
\text { phils or/and blast cells }\end{array}$ \\
\hline $\begin{array}{l}\text { Acute myeloid leukemia } \\
\text { Chronic myeloid leukemia }\end{array}$ & $\begin{array}{l}\text { myeloblasts } \\
\text { (rarely MCs) }\end{array}$ \\
\hline $\begin{array}{l}\text { Chronic eosinophilic leukemia } \\
\text { 2 Sryptase levels exceeding } 15 \text { ng/ml. }\end{array}$ & neoplastic MCs \\
\hline $\begin{array}{l}\text { tryptase levels, which may result from reduced excretion of the } \\
\text { enzyme. }\end{array}$ & \begin{tabular}{l} 
may present with elevated serum \\
\hline
\end{tabular} \\
\hline
\end{tabular}

basal tryptase level [23-25]. Table 2 shows an overview of conditions associated with an elevated serum tryptase level. In a group of otherwise healthy individuals, an increased basal serum tryptase level may be an indicator of MC hyper-responsiveness or occult allergy [12, 38]. In these patients, an MC activation syndrome should be considered when symptoms occur. In some of these patients, signs of MC monoclonality (e.g. KIT mutation $\mathrm{D} 816 \mathrm{~V}$ in a bone marrow sample) are found but criteria sufficient to diagnose SM are not met [17-19]. This condition is called 'monoclonal MCAS' [15, 18, 19]. If no signs of $\mathrm{MC}$ monoclonality or other underlying disorders are found, the condition is termed 'idiopathic MCAS' (table 3). All in all, monoclonal and idiopathic MCAS can be well differentiated from allergic diseases and primary MC disorders (table 3).

Measurement of Total IgE and Specific IgE, Skin Tests and Provocation Tests

In all patients with suspected or documented MC activation, further laboratory tests are performed including
Table 3. Major discriminative features in mastocytosis, MCAS, and allergic disorders

\begin{tabular}{|c|c|c|}
\hline Diagnosis & $\begin{array}{l}\text { Typical clinical } \\
\text { features }\end{array}$ & Key laboratory findings \\
\hline $\mathrm{CM}$ & $\begin{array}{l}\text { skin lesions (UP), } \\
+/- \text { mediator } \\
\text { symptoms }^{1}\end{array}$ & $\begin{array}{l}\text { positive skin histology, } \\
\text { SM criteria not met }\end{array}$ \\
\hline SM & $\begin{array}{l}+/ \text { - skin lesions } \\
\text { (UP-like), }+/- \text { me- }^{1} \\
\text { diator symptoms }^{1}\end{array}$ & $\begin{array}{l}\text { basal serum tryptase }>20 \\
\mathrm{ng} / \mathrm{ml} \text { (screen), SM } \\
\text { criteria fulfilled }\end{array}$ \\
\hline $\begin{array}{l}\text { Monoclonal } \\
\text { MCAS }\end{array}$ & $\begin{array}{l}\text { mediator symp- } \\
\text { toms }{ }^{1}, \text { no UP and } \\
\text { no signs of SM, +/- } \\
\text { allergy }^{2}\end{array}$ & $\begin{array}{l}\text { KIT D } 816 \mathrm{~V}+\text { cells found } \\
\text { in the bone marrow or } \\
\text { blood; } 1 \text { or } 2 \text { minor SM } \\
\text { criteria, but no major } \\
\text { SM criterion and in- } \\
\text { crease in tryptase during } \\
\text { an attack/event }\end{array}$ \\
\hline $\begin{array}{l}\text { Idiopathic } \\
\text { MCAS }\end{array}$ & $\begin{array}{l}\text { mediator symp- } \\
\text { toms }{ }^{1} \text {, no UP and } \\
\text { no signs of SM, no } \\
\text { allergy (negative } \\
\text { allergy test) }\end{array}$ & $\begin{array}{l}\text { no KIT D816V found, } \\
\text { no SM criteria, no spe- } \\
\text { cific IgE, but increase in } \\
\text { tryptase during an at- } \\
\text { tack/event }\end{array}$ \\
\hline $\begin{array}{l}\text { Allergy } \\
(\text { secondary } \\
\left.\text { MCAS }^{3}\right)\end{array}$ & $\begin{array}{l}\text { allergic reaction to } \\
\text { defined allergens, } \\
\text { no signs of UP or } \\
\text { SM, mediator } \\
\text { symptoms }{ }^{1}\end{array}$ & $\begin{array}{l}\text { specific IgE detecable } \\
\text { and }+/- \text { an increase in } \\
\text { tryptase during an aller- } \\
\text { gic reaction }{ }^{3} \text { (CM or SM } \\
\text { is rarely found) }\end{array}$ \\
\hline
\end{tabular}

MCAS = MC activation syndrome; UP = urticaria pigmentosa; $\mathrm{CM}=$ cutaneous mastocytosis; $\mathrm{SM}=$ systemic mastocytosis; $\operatorname{IgE}=$ immunoglobulin $\mathrm{E}$.

${ }^{1}$ In the context of MCAS, symptoms are considered to be caused by mediators released by MCs.

${ }^{2}$ In patients with monoclonal MCAS, allergy to hymenoptera venoms is found quite frequently.

${ }^{3}$ A transient and substantial increase in tryptase in an allergic reaction will argue for involvement of the MC lineage and thus for secondary MCAS. If no increase in tryptase is found during an anaphylactic reaction, basophil activation has to be considered (is the most likely explanation).

total serum IgE levels, specific IgE and other allergy tests. Skin tests should only be performed with caution in order to prevent further sensitization and provocation of attacks. The same holds true for all other types of provocation tests. An elegant approach is to examine cellular reactions to potential allergens. This is usually performed using basophils.

In most centers, basophil activation is determined by measuring allergen-induced upregulation of CD63 or 
Table 4. Commonly applied basophil and MC activation markers

\begin{tabular}{lllll}
\hline Marker/CD & Antigen & $\begin{array}{l}\text { Increase after IgE- } \\
\text { dependent activation of }\end{array}$ & Reference \\
\cline { 3 - 4 } & & & basophils & MCs \\
\hline CD13 & APN & + & n.k. & 61,62 \\
CD63 & LAMP3 & + & + & 39,40 \\
CD107a & LAMP1 & n.k. & + & 61,63 \\
CD107b & LAMP2 & + & + & 61,63 \\
CD164 & Endolyn & + & n.k. & 61 \\
CD203c & E-NPP3 & + & + & $42,44,46$ \\
\hline
\end{tabular}

APN = Aminopeptidase N; n.k. = not known; LAMP = lysosome-associated membrane antigen; E-NPP3 = ectonucleotide pyrophosphatase/phosphodiesterase 3.

CD203c by flow cytometry, or by measuring mediator (histamine) release [39-45]. Today, it is standard to use recombinant allergens in such assays whenever possible. However, unfortunately, these assays can only be performed using basophils but not using MCs. On the other hand, most IgE-dependent reactions may produce similar or the same post-signaling events in basophils and MCs (table 4).

\section{Morphology and Phenotype of MCs}

Unfortunately, it is usually impossible to study the morphology and phenotype of MCs during or shortly after an anaphylactic episode. It also remains unknown whether activation-linked antigens such as CD63 would serve as markers of MC activation in lesional sites in the tissues. Another question is whether basal levels of activation-linked antigens on MCs are expressed at higher levels in allergic patients or patients with recurrent anaphylaxis compared with normal healthy controls. For most groups of patients, this question has no answer. However, in patients with mastocytosis, it has been described that the basal levels of CD63 and CD203c expressed on MCs do not correlate with the severity of mediator-related events [46].

\section{Histopathological Examination of Affected Organs and Bone Marrow Studies}

When SM is considered as a potential diagnosis, the bone marrow has to be examined in each case independent of the primary lesion site [47-49]. Bone marrow biopsies may reveal an increase in MCs, abnormal MC morphology, signs of $\mathrm{MC}$ activation (degranulation), an abnormal MC phenotype, or abnormal distribution or even focal accumulation of MCs. It is standard to apply immunohistochemistry to detect and enumerate (estimate) MCs and determine an aberrant MC phenotype. MCs are usually easily identified by using antibodies against tryptase, chymase, and KIT [47-49]. Additional markers are indicative of a primary underlying MC disease. In this regard, the most important marker antigen is CD25 [50, 51]. This antigen (low-affinity IL-2 receptor) is not expressed on normal (resting) MCs, but is usually expressed on neoplastic MCs in SM. Therefore, CD25 expression in MCs has been proposed as a minor diagnostic criterion of SM [52]. However, CD25 is sometimes also expressed on nonneoplastic (reactive) MCs in chronic inflammatory reactions. It remains unknown whether CD25 expression on MCs in these patients is indicative for MC activation or even MC monoclonality. Other surface markers that may be expressed aberrantly (at increased levels) on activated (reactive) MCs are summarized in table 4 . In practice, CD25 is the standard stain recommended for use in suspected SM. In patients with focal aggregates (clusters) of CD25+ MCs and thus suspected SM, additional diagnostic tests including molecular studies (KIT mutation analyses) have to be initiated.

\section{Underlying Disorders, Idiopathic MC Activation and Other Conditions}

A number of disorders may underlie acute or/and chronic MC activation. These include allergic and atopic diseases, mastocytosis, MC activation syndrome, autoimmune disorders, infections and other inflammatory disorders (table 5).

Allergy often manifests as acute episode(s) with or without chronic symptoms and with or without symptom-free intervals. One ore more organ systems may be involved. In most cases, the allergen (exogenous) and allergen-specific IgE are known and are responsible for $\mathrm{MC}$ activation through high-affinity IgE binding sites [4-10, 53-55]. Acute MC activation and anaphylaxis can usually be documented quite easily in these patients. However, in patients with concomitant diseases (e.g. comorbidities) or when symptoms are atypical, measurement of MC-derived mediators including histamine and tryptase is recommended.

Atopic disorders are a group of chronic diseases characterized by chronic activation of the immune system including MCs [56-58]. A genetic predisposition to react to allergens has been described [56-58]. In several instanc- 
Table 5. Disorders associated with MC activation

\begin{tabular}{|c|c|}
\hline Disorder & Mechanism of MC activation \\
\hline Allergy ${ }^{1}$ & $\begin{array}{l}\text { allergens (exogenous), superallergens, } \\
\text { specific IgE }\end{array}$ \\
\hline Atopic diseases ${ }^{1}$ & autoallergens and specific IgE \\
\hline $\begin{array}{l}\text { Autoimmune } \\
\text { diseases }^{1}\end{array}$ & $\begin{array}{l}\text { activated MCs (IgE, IgG, complement- } \\
\text { mediated) }\end{array}$ \\
\hline Infectious diseases $^{1}$ & $\begin{array}{l}\text { microbe-derived antigens, microbe-spe- } \\
\text { cific IgE }\end{array}$ \\
\hline Idiopathic MCAS & $\begin{array}{l}\text { MC hyperresponsiveness, IgE-binding } \\
\text { proteins? }\end{array}$ \\
\hline Monoclonal MCAS & $\begin{array}{l}\text { MC monoclonality, KIT hyperresponsive- } \\
\text { ness? }\end{array}$ \\
\hline SM & $\begin{array}{l}\text { MC/KIT hyperresponsiveness }{ }^{2} \text { ? Also note: } \\
\text { massive MC burden and coexisting allergy }\end{array}$ \\
\hline Other primary $\mathrm{MC}^{3}$ & $\begin{array}{l}\text { MC-activating signaling molecules with or } \\
\text { without increased MC }\end{array}$ \\
\hline \multicolumn{2}{|c|}{$\begin{array}{l}{ }^{1} \text { In these diseases, MC activation may also occur and may be } \\
\text { dged as secondary MCAS. } \\
{ }^{2} \text { In most patients with SM, the activating KIT mutation D } 816 \mathrm{~V} \\
\text { detectable. However, in some patients (with SM), no mediator- } \\
\text { lated symptoms develop. } \\
{ }^{3} \text { Non-SM disorders of MCs include cutaneous mastocytosis, } \\
\text { astocytomas, MC sarcoma and myelomastocytic leukemia. In } \\
\text { these situations, MC activation may occur and may represent } \\
\text { najor challenge for the physician. }\end{array}$} \\
\hline
\end{tabular}

es, autoallergens are detected, which points to a relationship to autoimmune disorders $[59,60]$. Correspondingly, most patients have a constantly elevated IgE level and chronic symptoms. One or more organ systems may be involved. In patients with acute episodes of MC activation and thus anaphylaxis, MC activation can be documented quite easily by histamine or tryptase measurements. By contrast, in atopic patients who develop only chronic mild symptoms, serum tryptase levels usually are within the normal range even if a substantial spontaneous mediator release from MCs in vitro is demonstrable (often seen in atopic individuals). On the other hand, such atopic patients may suddenly develop severe allergic reactions (even to exogenous allergens) with massive MC activation and a measurable increase in plasma histamine and serum tryptase.

Mastocytosis is defined by an increase and accumulation of MCs in various organ systems $[15,52]$. In cutaneous mastocytosis, the disease is confined to the skin [52] (table 3). By contrast, in SM, MC aggregates are found in various extracutaneous organs including the bone marrow $[15,49,52]$. Mediator-related symptoms caused by MC activation may develop in all variants of SM [50,52]. Symptoms range from mild to severe and may even be live-threatening, which is easily explained by the extensive numbers of MCs in these patients. However, there are also patients with SM and very high numbers of MCs, in whom no mediator-related symptoms are recorded for many years [52]. Therefore, in cutaneous mastocytosis and SM, additional triggering factors are considered to play a role in MC activation. The most important cofactor may be a coexisting allergy [13, 15-17]. In fact, in patients with SM and a known allergy, symptoms are often severe and difficult to control with standard antimediator-type drugs. Sometimes, it is quite difficult or even impossible to identify the triggering allergen in these patients. Hymenoptera venoms are typical triggers that behave like an allergen in SM although no specific IgE is detectable. Therefore, in patients with anaphylaxis after a bee or wasp sting, in whom no allergy is detected by standard tests (including the most sensitive basophil activation assay, i.e. the CD203c test), an occult form of mastocytosis (SM) should be considered. If the basal level of tryptase is elevated in such patients, the likelihood of SM is rather high [23-25].

A number of other conditions and disorders may be accompanied by acute or chronic MC activation. Among these are chronic inflammatory and autoimmune disorders, drug reactions, $\mathrm{MC}$ activation after physical triggers (physical exercise, pressure, high or low temperature), or various stress reactions. If no trigger is identified but MC activation is documented, the condition is called 'idiopathic MC activation'. In case of repeated attacks (at least 3 documented episodes) and after exclusion of all potential underlying disorders (including SM by a bone marrow biopsy), the patient should be diagnosed as suffering from idiopathic MCAS. Many of these patients are suffering from chronic urticaria and/or angioedema with or without systemic symptoms. In patients in whom monoclonal MCs (bearing CD25 and/or KIT D816V) are detected, a diagnosis of 'monoclonal MCAS' is appropriate $[15,17]$.

\section{Differential Diagnoses}

Once MC activation has been ruled out or is unlikely, it is important to envisage other differential diagnoses that may explain symptoms. This is important as such 
underlying disorders may cause continuous problems or may even arise from a life-threatening condition (occult cancer). Disorders that can be confused with MC activation include cardiovascular disorders, certain endocrine disorders/neoplasms, gastrointestinal disorders, skin diseases, various infectious diseases and neurologic or psychiatric disorders. It is important to explore patients carefully for additional signs, symptoms and laboratory parameters that can guide the physician to the correct final diagnosis. Serum tryptase should be determined in all symptomatic patients at first presentation and in the follow-up. In addition, histamine and/or its metabolites should be measured in plasma and urine. A special differential diagnosis is food poisoning, which may result from histamine or histamine metabolites present in wine, sea food, fish or other eatables. In these patients, symptoms resolve after a certain time interval, and tryptase levels usually are normal. Another condition that has been proposed is histamine intolerance. This condition is believed to result from reduced levels of histamine-degrading enzymes (DAO), which is extremely difficult to prove in individual patients for reasons described above. It remains unknown whether these patients indeed react inappropriately to small quantities of histamine or just have increased levels of histamine leading to a secondary decrease in histamine-degrading enzymes (substrate consumption). Interestingly, several of these patients turn out to suffer from an occult form of SM once their tryptase level is measured. Independent of the underlying disease, these patients may respond to a histamine-free diet and HR1 and HR2 blockers.

\section{Concluding Remarks and Future Perspectives}

$\mathrm{MC}$ activation is an emerging health problem that is related to an increasing incidence of allergic disorders, but also to other reasons such as food intolerance or an increase in environmental toxins. The severity of symptoms depends on many different factors, including the trigger and mediators involved and the presence of an underlying disorder (comorbidity). Of all underlying disorders, MC neoplasms may be the most dangerous ones because of the huge numbers of involved effector cells. For the future, it will be important to define robust criteria for clinical aspects and features of MC activation and related conditions like MCAS, and to merge all definitions and previous criteria into a global classification of $\mathrm{MC}$ disorders and pathologic MC reactions.

\section{References}

1 Austen KF: Systemic anaphylaxis in the human being. N Engl J Med 1974;291:661-664.

$\checkmark 2$ Serafin WE, Austen KF: Mediators of immediate hypersensitivity reactions. $\mathrm{N}$ Engl J Med 1987;317:30-34.

$\checkmark 3$ Simons FE: Anaphylaxis. J Allergy Clin Immunol 2010;125:S161-S181.

$\checkmark 4$ Webb LM, Lieberman P: Anaphylaxis: a review of 601 cases. Ann Allergy Asthma Immunol 2006;97:39-43.

$\checkmark 5$ Lieberman P: Epidemiology of anaphylaxis. Curr Opin Allergy Clin Immunol 2008;8: 316-320.

6 Peavy RD, Metcalfe DD: Understanding the mechanisms of anaphylaxis. Curr Opin Allergy Clin Immunol 2008;8:310-315.

7 Golden DB: What is anaphylaxis? Curr Opin Allergy Clin Immunol 2007;7:331-336.

-8 Finkelman FD, Boyce JA, Vercelli D, Rothenberg ME: Key advances in mechanisms of asthma, allergy, and immunology in 2009. J Allergy Clin Immunol 2010;125:312-318.

$\checkmark 9$ Metcalfe DD: Differential diagnosis of the patient with unexplained flushing/anaphylaxis. Allergy Asthma Proc 2000;21:21-24.
10 Müller UR, Haeberli G: The problem of anaphylaxis and mastocytosis. Curr Allergy Asthma Rep 2009;9:64-70.

11 González de Olano D, de la Hoz Caballer B, Núñez López R, Sánchez Muñoz L, Cuevas Agustín M, Diéguez MC, Alvarez Twose I, Castells MC, Escribano Mora L: Prevalence of allergy and anaphylactic symptoms in 210 adult and pediatric patients with mastocytosis in Spain: a study of the Spanish network on mastocytosis (REMA). Clin Exp Allergy 2007;37:1547-1555.

-12 Bonadonna P, Perbellini O, Passalacqua G Caruso B, Colarossi S, Dal Fior D, Castellani L, Bonetto C, Frattini F, Dama A, Martinelli G, Chilosi M, Senna G, Pizzolo G, Zanotti R: Clonal mast cell disorders in patients with systemic reactions to Hymenoptera stings and increased serum tryptase levels. J Allergy Clin Immunol 2009;123:680-686.

13 Metcalfe DD, Schwartz LB: Assessing anaphylactic risk? Consider mast cell clonality. J Allergy Clin Immunol 2009;123:687-688.
14 Donker ML, Bakker NA, Jaspers WJ, Verhage AH: Two patients with osteoporosis: initial presentation of systemic mastocytosis. J Bone Miner Metab 2008;26:199-202.

15 Valent P, Akin C, Escribano L, Fodinger M, Hartman K, Metcalfe DD, et al: Standards and standardization in mastocytosis: consensus statement on diagnostics, treatment recommendations and response criteria. Eur J Clin Invest 2007;37:435-453.

16 Ruëff F, Dugas-Breit S, Przybilla B: Stinging Hymenoptera and mastocytosis. Curr Opin Allergy Clin Immunol 2009;9:338-342.

17 Akin C: Anaphylaxis and mast cell disease: what is the risk? Curr Allergy Asthma Rep 2010;10:34-38.

>18 Sonneck K, Florian S, Müllauer L, Wimazal F, Födinger M, Sperr WR, Valent P: Diagnostic and subdiagnostic accumulation of mast cells in the bone marrow of patients with anaphylaxis: Monoclonal mast cell activation syndrome. Int Arch Allergy Immunol 2007;142:158-164. 
19 Akin C, Scott LM, Kocabas CN, KushnirSukhov N, Brittain E, Noel P, Metcalfe DD: Demonstration of an aberrant mast-cell population with clonal markers in a subset of patients with 'idiopathic' anaphylaxis. Blood 2007; 110:2331-2333.

20 Greenhawt M, Akin C: Mastocytosis and allergy. Curr Opin Allergy Clin Immunol 2007;7:387-392.

-21 Florian S, Krauth MT, Simonitsch-Klupp I, Sperr WR, Fritsche-Polanz R, Sonneck K, Födinger M, Agis $\mathrm{H}$, Böhm A, Wimazal F, Horny HP, Valent P: Indolent systemic mastocytosis with elevated serum tryptase, absence of skin lesions, and recurrent severe anaphylactoid episodes. Int Arch Allergy Immunol 2005; 136:273-280.

-22 Escribano L, Akin C, Castells M, Schwartz LB: Current options in the treatment of mast cell mediator-related symptoms in mastocytosis. Inflamm Allergy Drug Targets 2006;5: 61-77.

-23 Schwartz LB, Sakai K, Bradford TR, Ren S, Zweiman B, Worobec AS, Metcalfe DD: The alpha form of human tryptase is the predominant type present in blood at baseline in normal subjects and is elevated in those with systemic mastocytosis. J Clin Invest 1995;96: 2702-2710.

24 Schwartz LB, Irani AM: Serum tryptase and the laboratory diagnosis of systemic mastocytosis. Hematol Oncol Clin North Am 2000;14:641-657.

25 Sperr WR, Jordan JH, Fiegl M, Escribano L, Bellas C, Dirnhofer S, Semper H, Simonitsch-Klupp I, Horny HP, Valent P: Serum tryptase levels in patients with mastocytosis: correlation with mast cell burden and implication for defining the category of disease. Int Arch Allergy Immunol 2002;128:136141.

26 Schwartz LB: Mast cells: function and contents. Curr Opin Immunol 1994;6:91-97.

-27 Ring J, Darsow U: Idiopathic anaphylaxis. Curr Allergy Asthma Rep 2002;2:40-45.

$\checkmark 28$ Maintz L, Novak N: Histamine and histamine intolerance. Am J Clin Nutr 2007;85: 1185-1196.

29 Schwelberger HG: Histamine intolerance: a metabolic disease? Inflamm Res 2010;59: 219-221.

- 30 Hogan AD, Schwartz LB: Markers of mast cell degranulation. Methods. 1997;13:43-52.

- 31 Akin C, Metcalfe DD: Surrogate markers of disease in mastocytosis. Int Arch Allergy Immunol 2002;127:133-136.

- 32 Di Lorenzo G, Pacor ML, Vignola AM, Profita M, Esposito-Pellitteri M, Biasi D, Corrocher R, Caruso C: Urinary metabolites of histamine and leukotrienes before and after placebo-controlled challenge with ASA and food additives in chronic urticaria patients. Allergy 2002;57:1180-1186.
33 van Toorenenbergen AW, Oranje AP: Comparison of serum tryptase and urine $\mathrm{N}$ methylhistamine in patients with suspected mastocytosis. Clin Chim Acta 2005;359:7277.

34 Morel AM, Delaage MA: Immunoanalysis of histamine through a novel chemical derivatization. J Allergy Clin Immunol 1988; 82:646-654

35 Schwartz LB, Metcalfe DD, Miller JS, Earl H, Sullivan T: Tryptase levels as an indicator of mast-cell activation in systemic anaphylaxis and mastocytosis. N Engl J Med 1987;316: 1622-1626.

36 Schwartz LB: Diagnostic value of tryptase in anaphylaxis and mastocytosis. Immunol $\mathrm{Al}$ lergy Clin North Am 2006;26:451-463.

37 Sirvent AE, González C, Enríquez R, Fernández J, Millán I, Barber X, Amorós F: Serum tryptase levels and markers of renal dysfunction in a population with chronic kidney disease. J Nephrol 2010;23:282-290.

38 Ruëff F, Przybilla B, Biló MB, Müller U, Scheipl F, Aberer W, Birnbaum J, BodzentaLukaszyk A, Bonifazi F, Bucher C, Campi P, Darsow U, Egger C, Haeberli G, Hawranek T, Kucharewicz I, Küchenhoff $\mathrm{H}$, Lang $\mathrm{R}$, Quercia O, Reider N, Severino M, Sticherling M, Sturm GJ, Wüthrich B: Predictors of side effects during the buildup phase of venom immunotherapy for Hymenoptera venom allergy: the importance of baseline serum tryptase. J Allergy Clin Immunol 2010,126: 105-111.e5.

39 Sainte-Laudy J, Sabbah A, Vallon C, Guerin JC: Analysis of anti-IgE and allergen induced human basophil activation by flow cytometry. Comparison with histamine release. Inflamm Res 1998;47:401-408.

-40 Sanz ML, Sánchez G, Gamboa PM, Vila L, Uasuf C, Chazot M, Diéguez I, De Weck AL: Allergen-induced basophil activation: CD63 cell expression detected by flow cytometry in patients allergic to Dermatophagoides pteronyssinus and Lolium perenne. Clin Exp Allergy 2001;31:1007-1013.

-41 Platz IJ, Binder M, Marxer A, Lischka G, Valent P, Bühring HJ: Hymenoptera-venominduced upregulation of the basophil activation marker ecto-nucleotide pyrophosphatase/phosphodiesterase 3 in sensitized individuals. Int Arch Allergy Immunol 2001;126: 335-342.

42 Hauswirth AW, Natter S, Ghannadan M, Majlesi Y, Schernthaner GH, Sperr WR, Bühring HJ, Valenta R, Valent P: Recombinant allergens promote expression of CD203c on basophils in sensitized individuals. J Allergy Clin Immunol 2002;110:102109.

43 Valent P, Hauswirth AW, Natter S, Sperr WR, Bühring HJ, Valenta R: Assays for measuring in vitro basophil activation induced by recombinant allergens. Methods 2004;32: 265-270.
44 Bühring HJ, Streble A, Valent P: The basophil-specific ectoenzyme E-NPP3 (CD203c) as a marker for cell activation and allergy diagnosis. Int Arch Allergy Immunol 2004; 133:317-329.

45 de Weck AL, Sanz ML, Gamboa PM, Aberer W, Bienvenu J, Blanca M, Demoly P, Ebo DG, Mayorga L, Monneret G, Sainte-Laudy J: Diagnostic tests based on human basophils: more potentials and perspectives than pitfalls. Int Arch Allergy Immunol 2008; 146: 177-189.

-46 Hauswirth AW, Escribano L, Prados A, Nuñez R, Mirkina I, Kneidinger M, Florian S, Sonneck K, Vales A, Schernthaner GH, Sanchez-Muñoz L, Sperr WR, Bühring HJ, Orfao A, Valent P: CD203c is overexpressed on neoplastic mast cells in systemic mastocytosis and is upregulated upon $\operatorname{IgE}$ receptor cross-linking. Int J Immunopathol Pharmacol 2008;21:797-806.

-47 Horny HP, Sillaber C, Menke D, Kaiserling E, Wehrmann M, Stehberger B, Chott A, Lechner K, Lennert K, Valent P: Diagnostic value of immunostaining for tryptase in patients with mastocytosis. Am J Surg Pathol 1998;22:1132-1140.

48 Horny HP, Valent P: Diagnosis of mastocytosis: general histopathological aspects, morphological criteria, and immunohistochemical findings. Leuk Res 2001;25:543551.

49 Horny HP, Sotlar K, Sperr WR, Valent P: Systemic mastocytosis with associated clonal haematological non-mast cell lineage diseases: a histopathological challenge. J Clin Pathol 2004;57:604-608

50 Escribano L, Orfao A, Díaz-Agustin B, Villarrubia J, Cerveró C, López A, Marcos MA, Bellas C, Fernández-Cañadas S, Cuevas M, Sánchez A, Velasco JL, Navarro JL, Miguel JF: Indolent systemic mast cell disease in adults: immunophenotypic characterization of bone marrow mast cells and its diagnostic implications. Blood 1998;91:2731-2736.

-51 Sotlar K, Horny HP, Simonitsch I, Krokowski M, Aichberger KJ, Mayerhofer M, Printz D, Fritsch G, Valent P: CD25 indicates the neoplastic phenotype of mast cells: a novel immunohistochemical marker for the diagnosis of systemic mastocytosis (SM) in routinely processed bone marrow biopsy specimens. Am J Surg Pathol 2004;28:1319-1325.

52 Valent P, Horny HP, Escribano L, Longley BJ, Li CY, Schwartz LB, Marone G, Nuñez R, Akin C, Sotlar K, Sperr WR, Wolff K, Brunning RD, Parwaresch RM, Austen KF, Lennert K, Metcalfe DD, Vardiman JW, Bennett JM: Diagnostic criteria and classification of mastocytosis: a consensus proposal. Leuk Res 2001;25:603-625. 
53 Valenta R, Kraft D: From allergen structure to new forms of allergen-specific immunotherapy. Curr Opin Immunol 2002;14:718727.

54 Taube C, Stassen M: Mast cells and mast cellderived factors in the regulation of allergic sensitization. Chem Immunol Allergy 2008; 94:58-66.

55 Rivera J, Fierro NA, Olivera A, Suzuki R: New insights on mast cell activation via the high affinity receptor for IgE. Adv Immunol 2008;98:85-120.

56 Johansson SG, Bieber T, Dahl R, Friedmann PS, Lanier BQ, Lockey RF, Motala C, Ortega Martell JA, Platts-Mills TA, Ring J, Thien F, Van Cauwenberge P, Williams HC: Revised nomenclature for allergy for global use: report of the Nomenclature Review Committee of the World Allergy Organization, October 2003. J Allergy Clin Immunol 2004;113: 832-836.
57 Mittermann I, Aichberger KJ, Bünder R, Mothes N, Renz H, Valenta R: Autoimmunity and atopic dermatitis. Curr Opin Allergy Clin Immunol. 2004;4:367-371.

58 Barnes KC: An update on the genetics of atopic dermatitis: scratching the surface in 2009. J Allergy Clin Immunol 2010;125:1629.e1-e11; Quiz 30-31.

59 Valenta R, Duchêne M, Pettenburger K, Sillaber C, Valent P, Bettelheim P, Breitenbach M, Rumpold H, Kraft D, Scheiner O: Identification of profilin as a novel pollen allergen; $\operatorname{IgE}$ autoreactivity in sensitized individuals. Science 1991;253:557-560.

60 Valenta R, Natter S, Seiberler S, Wichlas S, Maurer D, Hess M, Pavelka M, Grote M, Ferreira F, Szepfalusi Z, Valent P, Stingl G: Molecular characterization of an autoallergen, Hom s 1, identified by serum IgE from atopic dermatitis patients. J Invest Dermatol 1998;111:1178-1183.
61 HennersdorfF, Florian S, Jakob A, Baumgärtner K, Sonneck K, Nordheim A, Biedermann T, Valent P, Bühring HJ: Identification of CD13, CD107a, and CD164 as novel basophil-activation markers and dissection of two response patterns in time kinetics of IgE-dependent upregulation. Cell Res 2005; 15:325-335.

62 Sonneck K, Baumgartner C, Rebuzzi L, Marth K, Chen KW, Hauswirth AW, Florian S, Vrtala S, Bühring HJ, Valenta R, Valent P: Recombinant allergens promote expression of aminopeptidase-n (CD13) on basophils in allergic patients. Int J Immunopathol Pharmacol 2008;21:11-21.

63 Grützkau A, Smorodchenko A, Lippert U, Kirchhof L, Artuc M, Henz BM: LAMP-1 and LAMP-2, but not LAMP-3, are reliable markers for activation-induced secretion of human mast cells. Cytometry A 2004;61:6268. 